\title{
24. REMANENCE CHARACTERISTICS OF GABBROS FROM THE MARK AREA: IMPLICATIONS FOR CRUSTAL MAGNETIZATION
}

\author{
Jeff S. Gee, ${ }^{2}$ Róisín M. Lawrence, ${ }^{3}$ and Stephen D. Hurst ${ }^{3}$
}

\begin{abstract}
Although the general concept of linear magnetic anomalies generated by seafloor spreading processes is well established, the details of the source distribution responsible for these anomalies remain uncertain. We summarize here magnetic properties from variably altered and deformed olivine gabbro, gabbro, and less abundant troctolite, gabbronorite, and oxide gabbros sampled at four sites drilled on the western median valley wall of the Mid-Atlantic Ridge south of the Kane Fracture Zone. The overall mean natural remanent magnetization (NRM) intensity $(1.54 \pm 2.6 \mathrm{~A} / \mathrm{m})$ and Koenigsberger ratio $(8.05 \pm 15.2)$ for these samples suggest that lower crustal gabbros are a significant contributor to marine magnetic anomalies. However, dual magnetic polarities were recorded at all four sites, with apparent polarity reversals sometimes occurring over spatial scales of tens of centimeters. Detailed demagnetization and rock magnetic studies of one such interval suggest that the complex remanence, dual polarities, and the occurrence of spurious well-defined magnetization components are related to production of magnetite during high-temperature alteration and/or cooling in periods of opposite polarity. These complexities, if generally applicable to oceanic gabbros, may reduce the integrated contribution from the gabbroic layer to marine magnetic anomalies.
\end{abstract}

\section{INTRODUCTION}

Since their discovery (Mason and Raff, 1961), lineated marine magnetic anomalies have been widely used to reconstruct the tectonic history of the ocean basins. The relative widths of the anomalies also serve as a template for the geomagnetic reversal time scale (Heirtzler et al., 1968). Although the general concept of linear magnetic anomalies generated by seafloor spreading processes is well established, the details of the source distribution responsible for these anomalies remain uncertain. Early models incorporated a thick $(\sim 20 \mathrm{~km})$ source layer, whose lower boundary approximated the depth of the magnetite Curie point isotherm (Vine and Matthews, 1963). Subsequent studies of near-bottom magnetic anomalies (Talwani et al., 1971) and ridge-crest basalts (Irving, 1970) suggested that a thin $(\sim 0.5 \mathrm{~km})$, intensely magnetized $(5-15 \mathrm{~A} / \mathrm{m})$ extrusive layer adequately accounts for the anomalies at many ridge crests.

Although a thin extrusive source layer may be appropriate in the near ridge environment, a significant contribution from deeper source layers is apparently required for older oceanic crust. Compilation of results from the Deep Sea Drilling Project (DSDP) and the Ocean Drilling Program (ODP) suggests that the average magnetization of basalts $>2 \mathrm{~m}$.y. old is $\sim 3.5 \mathrm{~A} / \mathrm{m}$ (Johnson and Pariso, 1993). This low average magnetization value implies a source layer thickness of more than $1 \mathrm{~km}$ (Lowrie, 1977), thereby suggesting a contribution from the sheeted dikes and/or the gabbroic layer. Studies of polarity transition widths and anomaly shapes also imply a significant contribution from sources deeper than the extrusive layer (Cande and Kent, 1976; Blakely, 1976).

Direct samples of the sheeted dikes and gabbros are sparse and, until recently, our understanding of the magnetic properties of these units has relied heavily on results from dredged material (Fox and Opdyke, 1973; Kent et al., 1978) and ophiolites (Banerjee, 1980). The wide range of intensities recorded in these samples (see Smith, 1990 , for a review) has made it difficult to assess the potential contribution of deeper magnetic sources to marine magnetic anomalies.

'Karson, J.A., Cannat, M., Miller, D.J., and Elthon, D. (Eds.), 1997. Proc. ODP, Sci. Results, 153: College Station, TX (Ocean Drilling Program).

${ }^{2}$ Scripps Institution of Oceanography, La Jolla, CA 92093-0215, U.S.A. jsgee@ucsd.edu

3.Department of Geology, Duke University, Durham, NC 27708, U.S.A.
Recovery of $435 \mathrm{~m}$ of variably altered and deformed gabbro from Hole $735 \mathrm{~B}$ provided the first significant data set of the magnetic properties of lower crustal material. Although the average effective remanent magnetization $(2.5 \mathrm{~A} / \mathrm{m})$ and consistent stable inclination of the section imply a significant contribution to marine magnetic anomalies (Pariso and Johnson, 1993a), the high proportion (27\%) of oxide gabbros and the tectonic setting of the site make extrapolation of these results uncertain. More recently, a $155-\mathrm{m}$ section (30\% recovery) of gabbronorite ( $80 \%$ ), olivine gabbro, and gabbro was sampled at Site 894 on an intrarift ridge at Hess Deep (Shipboard Scientific Party, 1993). Although inclinations have been affected by rifting, the moderate intensity $(\sim 2.0 \mathrm{~A} / \mathrm{m})$ of gabbro samples from Hole $894 \mathrm{G}$ corroborates the general magnetic properties of the more extensive gabbroic section sampled from Hole 735B.

We present here initial magnetic results from four drill sites (Sites 921-924) in the Mid-Atlantic Ridge south of the Kane Fracture Zone (MARK) area that provide further indication of the probable importance of the gabbroic layer as a source for marine magnetic anomalies. All four sites lie on the western median valley wall of the MidAtlantic Ridge, some $10 \mathrm{~km}$ west of the median neovolcanic ridge and 10-12 km south of the Kane Fracture Zone (Fig. 1). A total of $117 \mathrm{~m}$ of variably altered and deformed olivine gabbro, gabbro, and a lesser amount of troctolite, gabbronorite, and oxide gabbro was recovered at the four sites, representing a cumulative recovery of $26 \%$ of the drilled material. Two-dimensional forward modeling of seasurface magnetic anomalies (Schulz et al., 1988) suggests an age of $\sim 1$ m.y. for the gabbroic rocks sampled during Leg 153. Dual magnetic polarities (sometimes within a single contiguous recovered piece) were recorded at all four sites, although reversed polarity samples dominate at Sites 921 and 923, and normal polarity samples are most prevalent at Sites 922 and 924 . In addition, a significant portion of the samples exhibit complex remanent magnetization, typically with two to three (but as many as five) distinct components of magnetization. These complexities, which presumably reflect cooling and/or alteration during intervals of opposite polarity near the Brunhes/Matuyama boundary, preclude a complete description of the shipboard and shore-based data at this time. In this paper, we therefore focus on two aspects of the data: the distribution and possible causes of variations in the natural remanent magnetization (NRM) and a detailed examination of a single core (Core 153-923A-9R) that exhibits dual polarities within a single section. 
Figure 1. Bathymetric map of the western median valley wall of the Mid-Atlantic Ridge south of the Kane Fracture Zone. Alvin and Nautile dive tracks and location of Sites 921-924 are indicated (from Shipboard Scientific Party, 1995).

\section{METHODS}

Paleomagnetic measurements on board the JOIDES Resolution included susceptibility and remanence measurements on both archive-half cores and discrete samples. The remanence of continuous core pieces was measured using the 2-G Enterprises pass-through cryogenic magnetometer, equipped with a set of orthogonal coils capable of generating an alternating field (AF) of up to $25 \mathrm{mT}$. The width of the sensor response function limits the usefulness of the archive-half remanence data to continuous core pieces longer than $\sim 15$ $\mathrm{cm}$. A total of 120 discrete samples was subject to either stepwise AF or thermal demagnetization (using a Schonstedt GSD-1 or TSD-1, respectively), and subsequently measured using the Molspin magnetometer. At AF treatment steps $>30 \mathrm{mT}$, samples were routinely subjected to double demagnetization (i.e., samples were measured twice, once after demagnetization along three orthogonal axes and again after treatment along the opposite axial directions). Deviations between the two measurements facilitate recognition of spurious magnetizations acquired during demagnetization; in such cases, the vector average of the two measurements (if $<20^{\circ}$ apart) was used for plotting and determination of components. Bulk susceptibilities and the anisotropy of magnetic susceptibility were determined from of a series of 15 measurements on the Kappabridge KLY-2. Although most samples showed appreciable anisotropy (up to $\sim 25 \%$ directional variation), only the bulk susceptibility data are discussed here.

Shore-based remanence measurements were made on an additional 202 samples at the Lamont-Doherty Earth Observatory, Scripps Institution of Oceanography, and the University of California, Davis, paleomagnetism laboratories. Remanence measurements at all three laboratories were made in magnetically shielded rooms using 2-G cryogenic magnetometers comparabloto the magnetometer on board the JOIDES Resolution. To date, approximately two-thirds of the shore-based samples have been subjected to stepwise demagnetization. Alternating field demagnetization studies at Scripps and Lamont used a double demagnetization scheme identical to that described above; data from University of California, Davis, employed a single three-axis demagnetization throughout. Thermal demagnetization studies at University of California, Davis, utilized a Schonstedt oven. Both the Lamont and Scripps laboratories are equipped with threezone ovens, which allow closely spaced $\left(5^{\circ}-10^{\circ} \mathrm{C}\right)$, reproducible

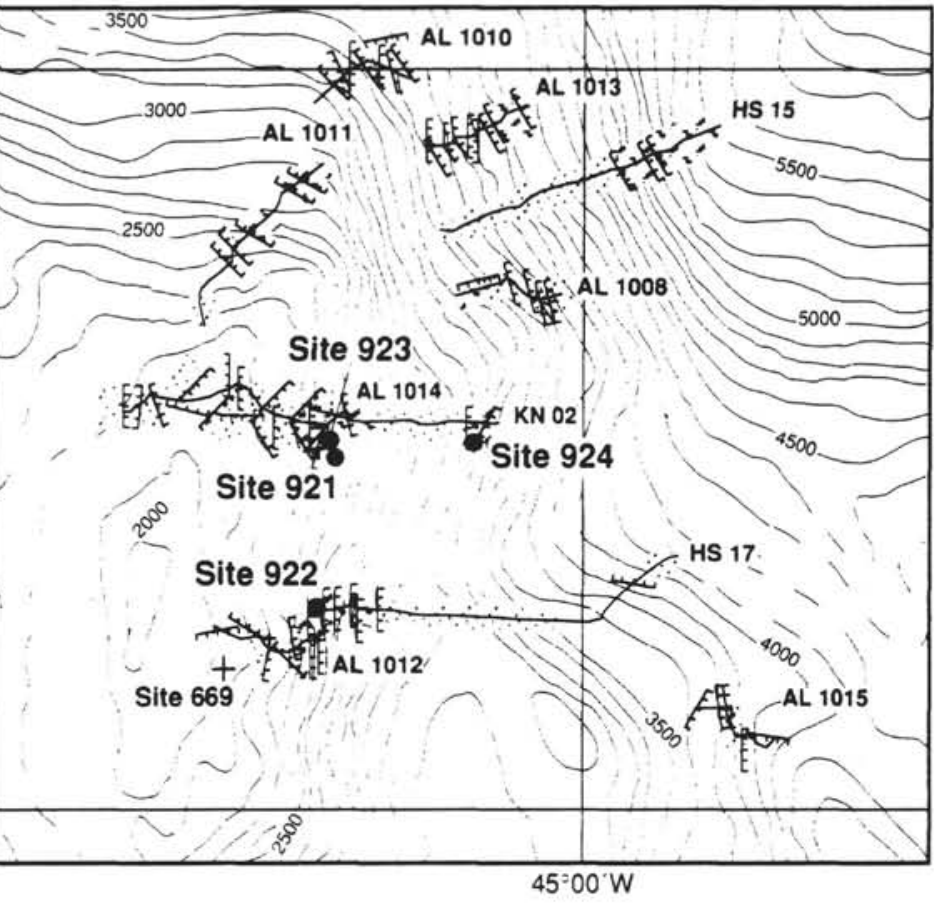

temperature steps. Susceptibility measurements at all laboratories were made using a Kappabridge KLY-2 identical to that used at sea. In addition, bulk susceptibility was measured between each thermal demagnetization step at Lamont and Scripps, as a monitor of irreversible mineralogical changes caused by heating. Best-fit magnetization directions were calculated for linear segments, identified by vector endpoint and equal-area projections, using principal component analysis (Kirschvink, 1980). In addition, the temperature dependence of high-field magnetization has been determined for a small number of samples using an Alpha Precision Instruments horizontal translation Curie balance. Samples (50-100 mg) were heated at $25^{\circ} \mathrm{C} / \mathrm{min}$ in air in a field of $\sim 150 \mathrm{mT}$; Curie points were determined from maxima in the second derivative of the heating curve.

\section{RESULTS}

\section{Natural Remanent Magnetization and Koenigsberger Ratio (Q)}

The most relevant parameters for comparison with sea-surface magnetic anomaly data are the NRM and susceptibility, from which the induced magnetization may be calculated. These basic magnetic parameters are summarized by site in Table 1 and by lithology in Figure 2. The range of NRM intensities in gabbros from Leg 153 is substantial, spanning nearly four orders of magnitude. For olivine gabbros, the number of samples (225) is sufficient to suggest that the distribution of intensities is essentially log normal (Fig. 2), as has been noted previously for a number of remanence data sets (e.g., Kono, 1980). Although the standard deviation values are substantial, we note that the mean intensities for Sites 921 and 923, which have predominantly reversed polarity characteristic remanence directions, are marginally lower than those of the dominantly normal polarity gabbros from Sites 922 and 924 . As discussed below, the near ubiquitous presence of a downward directed, drilling-induced remanence and the common occurrence of an additional normal polarity overprint may, in part, be responsible for this discrepancy in mean NRM intensities.

Previous studies suggest that both lithology and degree of alteration may be important factors in determining the remanent magnetization of gabbroic samples. In particular, magnetite in cumulate gab- 
bros is thought to be largely a product of high-temperature alteration of pyroxene and olivine, whereas the amount of primary magnetite in oxide-rich gabbros is thought to essentially reflect the degree of crystal fractionation from a tholeiitic melt (Pariso and Johnson, 1993b). Shipboard paleomagnetic samples from Leg 153 were used for physical properties and geochemical analyses whenever possible, facilitating a direct evaluation of the role of bulk-rock geochemistry in NRM intensity variations (Fig. 3A). Direct correspondence of geochemical and magnetic sampling on previous ODP legs has been less common, although a small number of magnetic samples from Holes $735 \mathrm{~B}$ and $894 \mathrm{G}$ did have corresponding geochemical data from the same (or an immediately adjacent) subpiece. An additional 29 gabbroic samples with both remanence and geochemical data are available from Alvin dives on the north wall of Hess Deep (J. Natland, unpubl. data). Together, these data suggest a broad trend towards higher NRM values with increasing degree of fractionation (decreas-

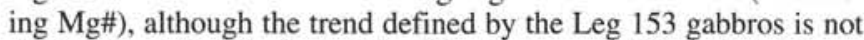
obviously related to that defined by the more differentiated lavas from Hess Deep. Kikawa and Ozawa (1992) have noted a comparable increase in remanent intensity in gabbros from Hole 735B as fractionation proceeds from troctolite to olivine gabbro (Mg\# of clinopyroxene 0.87 to 0.77 ).

Various earlier studies provide conflicting results concerning the role of alteration in controlling magnetic remanence. Swift and Johnson (1984) reported an increase in NRM intensity with increasing alteration in gabbros from the Bay of Islands ophiolite. In contrast, more recent studies of dredged and drilled material seem to indicate little systematic change (Kent et al., 1978; Pariso and Johnson, 1993b) or even a decrease in NRM intensity with increasing alteration (Kikawa and Ozawa; 1992). Shipboard determinations of the qualitative degree of alteration (negligible $<2 \%$; slight $2 \%-10 \%$; moderate $10 \%-40 \%$; high $40 \%-80 \%$; and pervasive $80 \%-100 \%$; Cannat, Karson, Miller, et al., 1995) allow a first-order assessment of its importance in controlling variations in remanent intensity in Leg 153 gabbros. Arithmetic means for these qualitative groupings provide little evidence for systematic changes with increasing degree of alteration (Fig. 3B). Even the least altered samples have moderate $(\sim 0.5 \mathrm{~A} / \mathrm{m})$ intensities, although extremely low NRM intensities $(<0.05 \mathrm{~A} / \mathrm{m})$ are restricted to samples that have undergone pervasive alteration.

The Koenigsberger ratio $(\mathrm{Q}$; the ratio of the remanent to induced magnetization) was calculated for samples from Leg 153 using the International Geomagnetic Reference Field value (30.62 A/m) appropriate for the MARK area. The range of values is large (0.59-177), and as with the remanence data, the underlying distribution is apparently $\log$ normal (Fig. 2). With the exception of only 5 samples, Q > 1.0 for all gabbros from Leg 153 indicating that the in situ magnetization, at least at low temperatures, will be dominated by the remanent contribution. The mean Q value for the entire data set (arithmetic mean $7.78 \pm 10.9$ ) implies that induced magnetization will contribute approximately $10 \%$ of the total magnetization.

\section{Demagnetization Data}

Gabbros from Leg 153 exhibit a wide range of demagnetization behavior, from nearly univectorial remanence decay to samples with four or more resolvable components. Representative demagnetization diagrams are shown in Figure 4. A small number of samples

Table 1. Summary magnetic properties for Leg 153 gabbros.

\begin{tabular}{cccccc}
\hline Site & $\begin{array}{c}\text { Number of } \\
\text { samples }\end{array}$ & & $\begin{array}{c}\text { NRM } \\
(\mathrm{A} / \mathrm{m})\end{array}$ & $\begin{array}{c}\text { Koenigsberger } \\
\text { ratio }(\mathrm{Q})\end{array}$ & Susceptibility \\
\hline 921 & $98(84)$ & A.M. & $1.03(1.45)$ & $7.46(13.4)$ & $5.64(3.81)$ \\
& & G.M. & $0.55(0.47)$ & $4.06(0.40)$ & $4.67(0.28)$ \\
922 & $59(44)$ & A.M. & $2.16(4.41)$ & $3.96(1.87)$ & $14.4(20.9)$ \\
& & G.M. & $0.74(0.80)$ & $3.39(0.27)$ & $6.46(0.66)$ \\
923 & $139(105)$ & A.M. & $1.27(1.45)$ & $9.34(19.8)$ & $5.84(4.48)$ \\
924 & \multirow{2}{*}{$26(20)$} & G.M. & $0.83(0.41)$ & $5.75(0.34)$ & $4.67(0.30)$ \\
& & G.M. & $3.49(4.07)$ & $12.77(8.92)$ & $12.3(16.0)$ \\
$921-924$ & $322(253)$ & A.M. & $1.92(0.52)$ & $10.71(0.25)$ & $5.01(0.64)$ \\
& & & & & \\
\hline
\end{tabular}

Notes: Number of samples in parentheses is for Q and susceptibility. A.M. = arithmetic mean with 1 standard deviation. G.M. = geometric mean with 1 standard deviation expressed in log units.
A
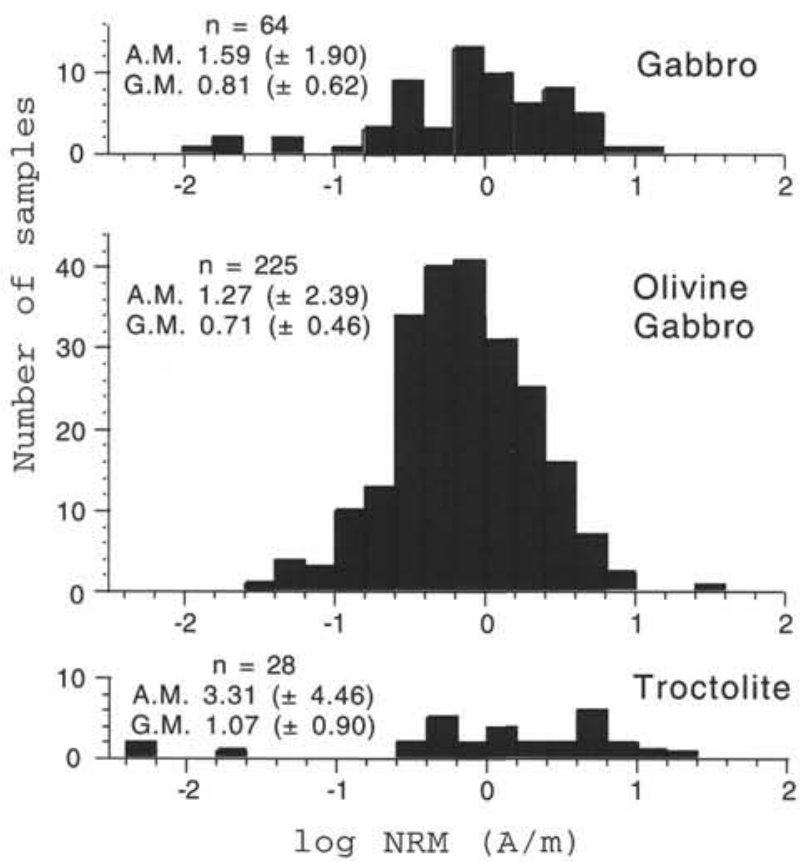

B
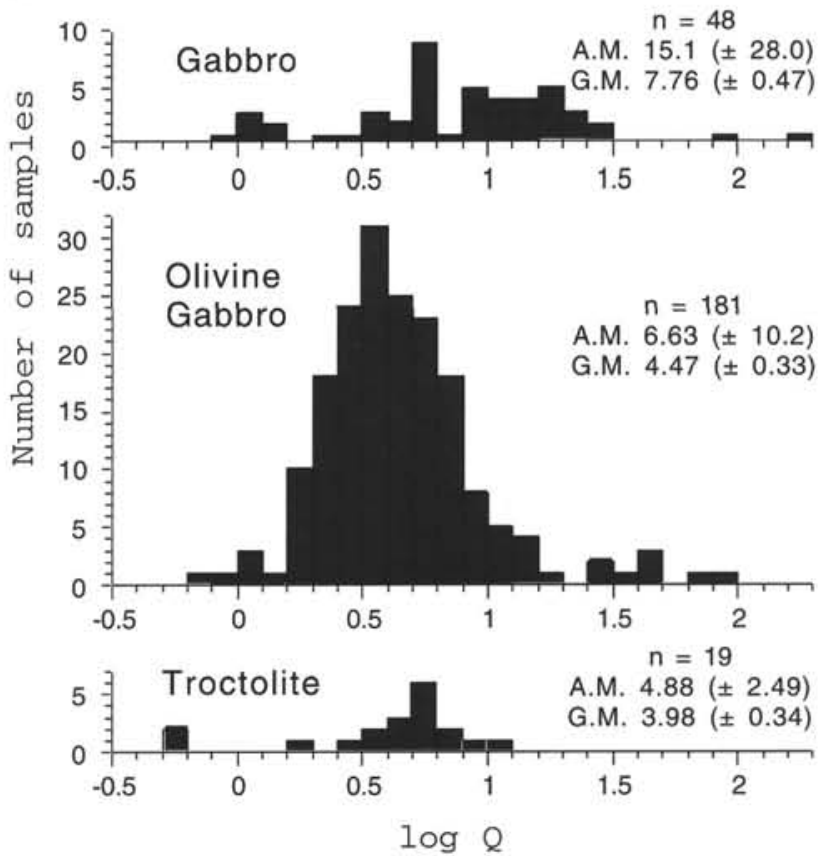

Figure 2. Distribution of (A) NRM and (B) Koenigsberger ratio (Q) for major lithologies recovered during Leg 153. Arithmetic (A.M.) and geometric (G.M.) means and associated errors ( 1 standard deviation; in log units for geometric mean) are given for reference. 

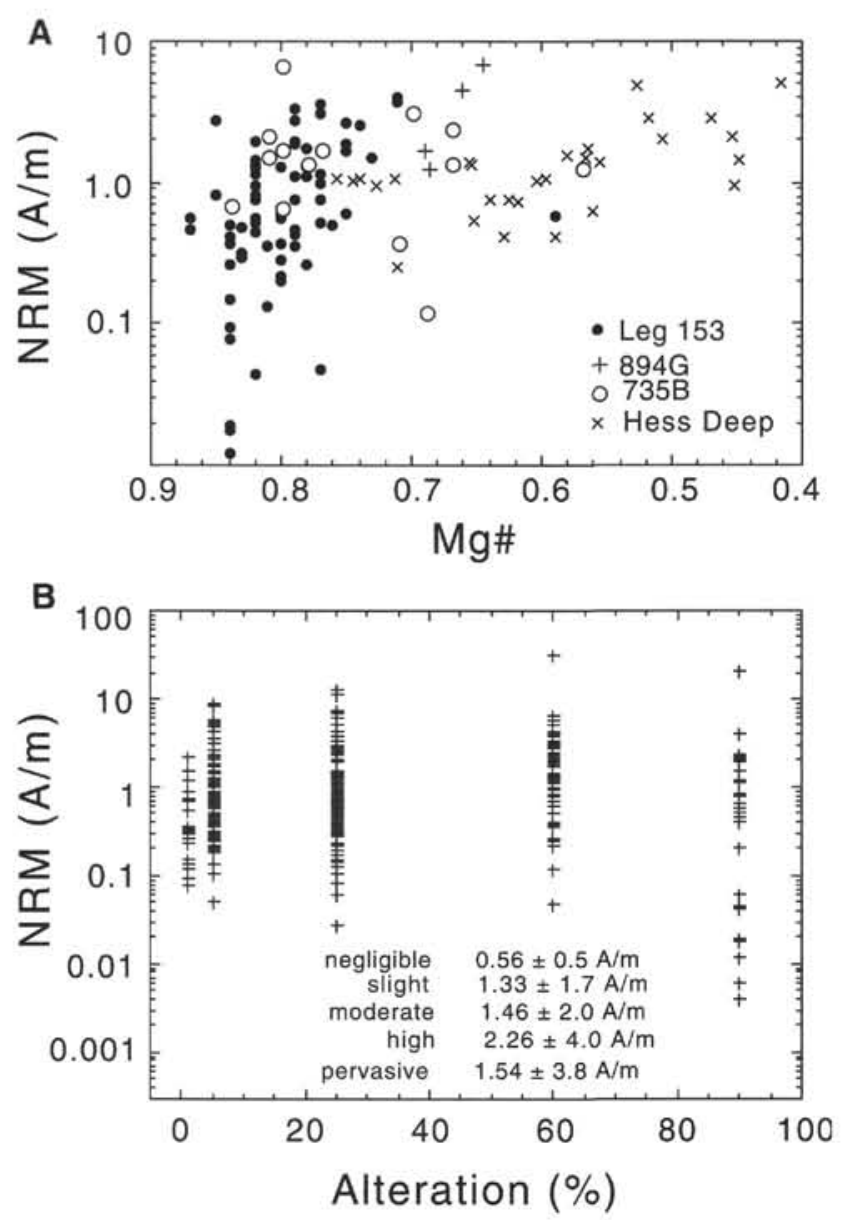

Figure 3. A. Variation of NRM of oceanic gabbros as a function of $\mathrm{Mg} \#$ $\left(\mathrm{Mg}^{2+} /\left[\mathrm{Fe}^{2+}+\mathrm{Mg}^{2+}\right]\right)$. Data for Hole 894G (Hess Deep), Hole 735B, and Leg 153 are from shipboard samples with XRF data from the same piece or an adjacent subpiece (Shipboard Scientific Party, 1989, 1993; Cannat, Karson, Miller, et al., 1995). Additional data from Hess Deep (x) are from Alvin dive samples (J. Natland, unpubl. data). B. Variation of NRM intensity in Leg 153 gabbros as a function of degree of alteration.

$(\sim 5 \%)$ have univectorial, or nearly univectorial, remanence decay (Fig. 4A). These samples typically have high stability to AF demagnetization (median destructive fields [MDFs] of 50 to $>100 \mathrm{mT}$ ) and discrete unblocking temperatures above $500^{\circ} \mathrm{C}$. Nearly all remaining samples have a variable magnitude, steeply inclined, low stability component that is presumably related to drilling (Figs. 4B, 4E). Following removal of this component (by $10-20 \mathrm{mT}$ ), approximately $40 \%$ of the samples have either a normal or reversed polarity component that decays towards the origin (Fig. 4B). The remaining samples have more complex remanent magnetizations, where a final stable magnetization direction cannot be unambiguously identified (Figs. 4C, 4E, 4F). These samples typically have significantly lower MDF or distributed unblocking temperature spectra, though maximum unblocking temperatures near $575^{\circ} \mathrm{C}$ are characteristic of the entire sample set.

Comparison of shipboard thermal and AF demagnetization on immediately adjacent samples (Figs. 4D, 4E, 4F) in some cases revealed significant differences in the components isolated by the two techniques. The discrepancy in the final component isolated in these three samples from the same section (two from the same core piece and all within $35 \mathrm{~cm}$ ) suggests either that significant overlap exists in the blocking temperature spectra of the components isolated by AF demagnetization or that sample heterogeneity exists on a centimeter scale within the cores. To evaluate this possibility more fully, 18 pairs of adjacent samples (two minicores within $5 \mathrm{~cm}$ ) were subjected to detailed demagnetization studies. One sample from each pair was split using a low speed saw. The first piece was AF demagnetized to $10 \mathrm{mT}$ to remove most, if not all, of the drilling-related remanence, and then both halves were subjected to detailed thermal demagnetization. The sister sample from each pair was AF demagnetized. The first notable result from this experiment is that significant heterogeneity in the NRM does indeed exist on a centimeter scale, as the initial remanence of the two halves of the split sample differed by as much as $50^{\circ}$. However, in all cases, the vector sum of the remanence from the two halves was nearly identical to the pre-splitting remanence, indicating that the differences did not arise from the cutting procedure.

Demagnetization results from two of these sample pairs (Fig. 5) illustrate the extent of fine-scale remanence heterogeneity in gabbros from Leg 153. For the sample pair shown in the upper portion of this figure, thermal demagnetization of the two split samples (Figs. 5A, $5 \mathrm{~B})$ recovered essentially the same components, although the relative magnitudes of these components differ considerably. Both subsamples have similar (southwest, down) magnetization components removed at $200^{\circ}-475^{\circ} \mathrm{C}$ and $550^{\circ}-580^{\circ} \mathrm{C}$, separated by a shallow (east, up) component that is mainly unblocked between $475^{\circ}$ and $540^{\circ} \mathrm{C}$. The corresponding AF-demagnetized sample (Fig. 5C) has a low-stability (10-25 mT) component similar to the southwest, down component isolated by thermal demagnetization. The highest stability magnetization has a direction similar to that of the intermediate component from the thermal demagnetization curves, although no stable final direction could be isolated by AF demagnetization. The second pair of samples (Figs. 5D-5F) more clearly illustrates that large differences in demagnetization behavior may exist within a single minicore. In this case, the final component recovered in the two split samples is of different polarity (Figs. 5D, 5E). The final northwest, up magnetization direction isolated in Sample 153-923A-9R-1 (30-33 $\mathrm{cm}$, subsample A) and the corresponding AF-demagnetized sample (Fig. 5F) is evident only as a poorly defined intermediate component (at temperatures of $530^{\circ}-550^{\circ} \mathrm{C}$ ) in Sample 153-923E-9R1 (30-33 $\mathrm{cm}$, subsample B). This large within-sample discrepancy may in part reflect the initial $\mathrm{AF}$ demagnetization to $10 \mathrm{mT}$, suggesting that the drilling induced remanence (which is easily removed by AF demagnetization) may have affected multidomain grains with unblocking temperatures that extend to Curie point of magnetite (Shcherbakov et al., 1993).

Dual polarity was documented from both whole-core remanence data and discrete sample demagnetization data for all four gabbro sites drilled during Leg 153 . In several instances apparent polarity reversals occurred within a single section or even within a single contiguous core piece as illustrated for Core 153-923A-9R (Fig. 6). Both normal and reversed polarity persist within Piece 8 (Core 153-923A9R) after demagnetization at $20 \mathrm{mT}$, a peak field that should be sufficient to remove any drilling-induced remanence. Five discrete samples from Pieces $8 \mathrm{~A}$ and $8 \mathrm{~B}$ (Fig. 7) provide a particularly strong test of the origin of dual polarities as these samples all have a common azimuthal orientation. Again, split halves of the same minicore subjected to combined $10 \mathrm{mT}$ and thermal demagnetization and thermal demagnetization alone yield significantly different directions during progressive demagnetization (Figs. 7A, 7B, 7E, 7F). The final component in five of the seven samples from Piece 8, however, is of normal polarity as might be predicted on the basis of the whole-core remanence data. The reversed polarity characteristic magnetization of Sample 153-923A-9R-2, 93-96 cm (Fig. 7G) is generally consistent with the negative inclinations in the lower portion of Piece 8 noted in the whole-core data (Fig. 6).

The uniform azimuthal orientation of all five minicore samples allows complete analysis of the demagnetization behavior of these seven subsamples. Best-fit planes were calculated for the demagnetization steps corresponding to all well-defined components (maximum angular deviation $[\mathrm{MAD}]$ angles $\left\langle\sim 10^{\circ}\right.$ ) in the subsamples shown in Figure 7. Despite the variety of magnetization components evident in Figure 7, the best-fit planes for all but the lowest stability component 
A

$$
\begin{gathered}
\text { Sample } 153-923 A-13 R-3 \\
(50-53 \mathrm{~cm})
\end{gathered}
$$

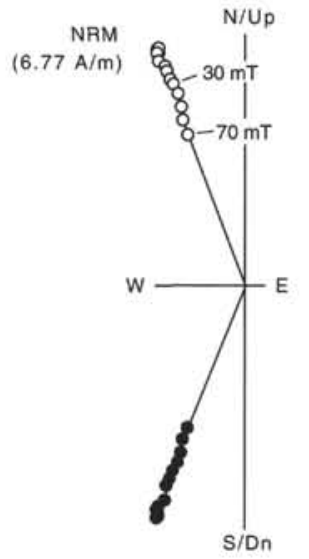

D

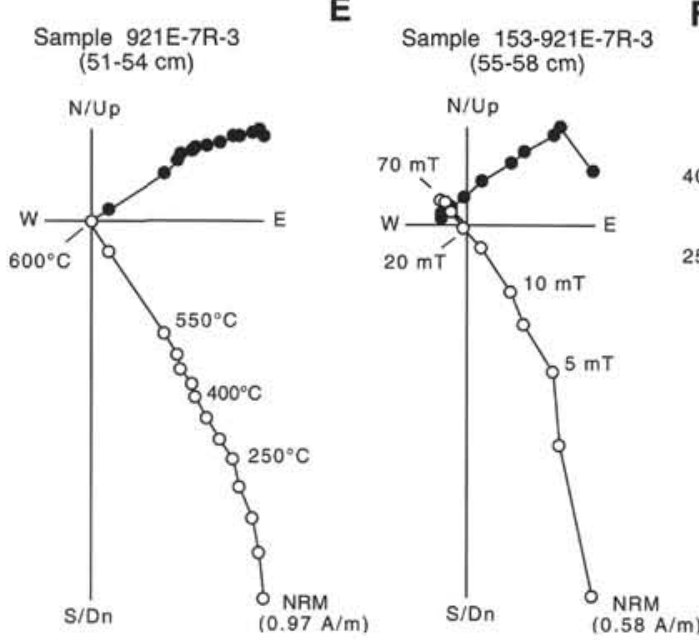

Sample 153-922A-1R-1 $(130-133 \mathrm{~cm})$

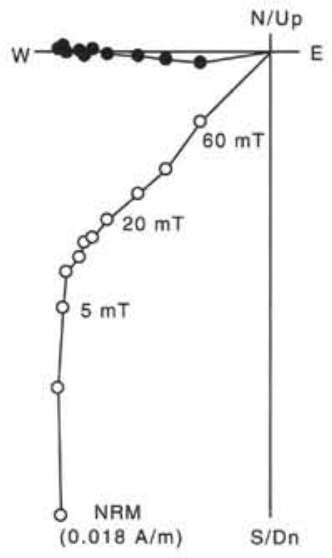

E
C

Sample 153-923A-14R-2 $(6-9 \mathrm{~cm})$

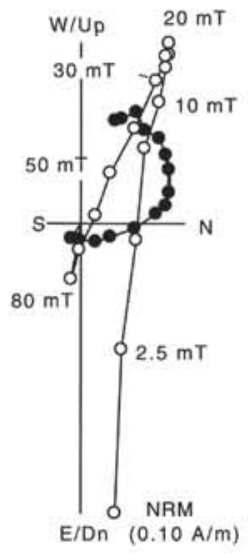

$\mathbf{F}$

Sample 153-921E-7R-3

$(83-86 \mathrm{~cm})$

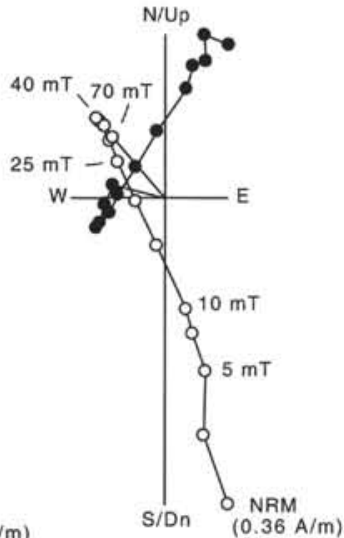

Figure 4. Representative vector endpoint diagrams for gabbro samples from Leg 153. A. Reversed polarity sample with univectorial demagnetization behavior. B. Normal polarity sample with moderate low stability overprint presumably related to drilling. C. Complex demagnetization behavior illustrating failure of AF demagnetization to isolate the characteristic magnetization. D-F. Three adjacent samples (taken over a $35-\mathrm{cm}$ span) from a single section illustrating the variability of the remanence within a single section. Open (solid) circles are projections onto the vertical (horizontal plane). (which is presumably related to drilling) are broadly consistent with great-circle paths between a single normal and a single reversed polarity direction. Analysis of the combined great-circle paths (McFadden and McElhinny, 1988), both with and without three well-defined normal polarity directions (azimuths near $300^{\circ}$ ), yields a mean inclination (approximately $\pm 50^{\circ}$ ) not substantially different from the expected geocentric axial dipole inclinations $\left( \pm 41^{\circ}\right)$ at this site (Fig. 8). Many of the principal components calculated from linear portions of the demagnetization data (solid and open circles in Fig. 8) evidently represent spurious intermediate directions along the great-circle paths. Although the occurrence of similar spurious, apparently single component, remanence directions has been previously documented (Dinares-Turell and McClelland, 1991; Gee et al., 1993), its occurrence in samples from Leg 153 underscores the importance of detailed demagnetization studies prior to use of remanence directions for reorientation of structural features.

\section{DISCUSSION}

The complex remanence, and particularly the observation of spurious magnetic components, suggests a potential explanation for the presence of dual polarity within cores sampled during Leg 153 . The presence of spurious magnetization components documented above requires substantial overlap of unblocking temperature (and sometimes coercivity) spectra. Such overlap of unblocking temperature spectra may be caused by three factors: the presence of partial thermoremanent magnetizations (pTRM) in two coexisting mineral phas- es, the presence of pTRMs in multidomain and single-domain grains of the same mineral, or chemical overprinting (McClelland-Brown, 1982). Coexistence of two distinct mineral phases is an unlikely mechanism in the Leg 153 gabbros for the following reasons. Unblocking temperature spectra for gabbros from Leg 153 typically show maximum unblocking between $\sim 500^{\circ}$ and $580^{\circ} \mathrm{C}$, with little if any evidence for unblocking temperatures expected for either pyrrhotite $\left(350^{\circ} \mathrm{C}\right)$ or hematite $\left(600^{\circ}-680^{\circ} \mathrm{C}\right)$. The dominance of Ti-free magnetite as the magnetic carrier in these rocks is further documented by Curie temperatures (Tc) determined for samples from Core 153-923A-9R (Fig. 9). Multiple chips were measured from each of 9 samples from this core. With one exception (Fig. 9D; Tc $=548^{\circ} \mathrm{C}$ ), the high-field magnetization variation with temperature indicates the presence of a single phase with a Curie temperature of $579^{\circ} \mathrm{C}\left( \pm 4^{\circ} \mathrm{C}\right)$. Furthermore, the presence of apparent dual polarities within a single contiguous core piece, and indeed from a single minicore, is difficult to reconcile with a simple cooling history resulting in the acquisition of distinct pTRMs in two mineral phases. Were this the case, all samples might be expected to record a similar pattern of polarity changes through cooling. However, the occurrence of markedly different apparent polarity histories in immediately adjacent samples with identical unblocking temperature spectra argues strongly against the presence of two distinct mineral phases.

The remaining two possibilities are difficult to distinguish, and the two processes may be closely related in these crustal gabbros. Pure magnetite is known to be produced by high-temperature alteration of olivine and clinopyroxene (Evans et al., 1968) as well as from exsolution in plagioclase grains (Davis, 1981). Complementary 
A

Sample 153-921E-7R-4 (25-28 cm; Subsample A)

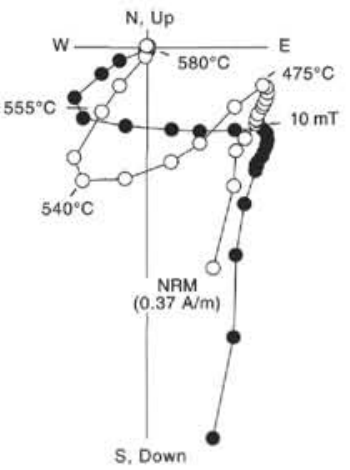

B

Sample 153-921E-7R-4 (25-28 cm; Subsample B)

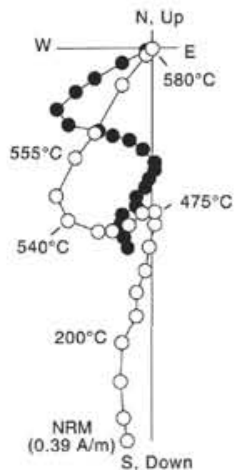

C

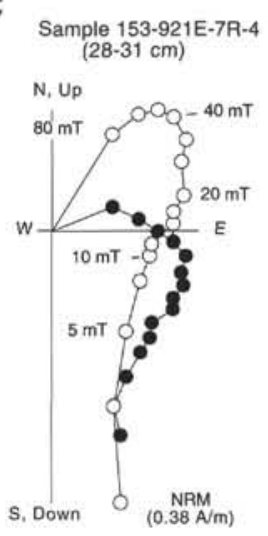

Figure 5. Vector endpoint diagrams illustrating the extreme within- and between-sample heterogeneity in some Leg 153 gabbro samples. Split samples from the same minicore subjected to (A) $10 \mathrm{mT} \mathrm{AF}$ demagnetization followed by thermal demagnetization and (B) thermal demagnetization differ greatly from (C) AF demagnetization of immediately adjacent sample. Split samples from the same minicore subjected to (D) $10 \mathrm{mT}$ AF demagnetization followed by thermal demagnetization and (E) thermal demagnetization alone exhibit final components of different polarity. The corresponding (F) AF demagnetization of the immediately adjacent sample apparently isolates a final component similar to that in (A). Open (solid) circles are projections onto the vertical (horizontal plane).
Figure 6. Whole-core remanence data $(\mathrm{NRM}=$ dashed; 20 $\mathrm{mT} \mathrm{AF}$ demagnetization $=$ solid) for Core 153-923A-9R illustrating the juxtaposition of reversed and apparent normal polarity intervals within a single core piece. Distribution of pieces and discrete sample locations are shown to the right. Samples from Piece 8 (gray) are the subject of detailed study (see also Figs. 5, 7, 8). Diagonal lines within core pieces indicate location of subpiece boundaries; relative azimuthal orientation should be preserved across these boundaries.
D

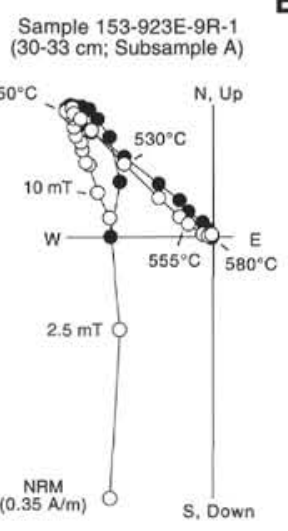

E

Sample 153-923E-9R-1 ( $30-33 \mathrm{~cm}$; Subsample B)

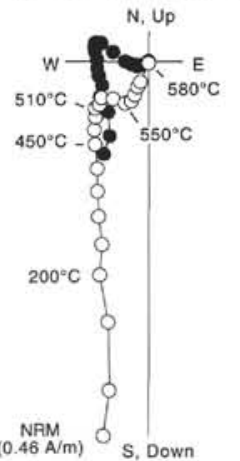

\section{$F_{\text {Sample 153-923E-9R-1 }}$ \\ $(33-36 \mathrm{~cm})$}

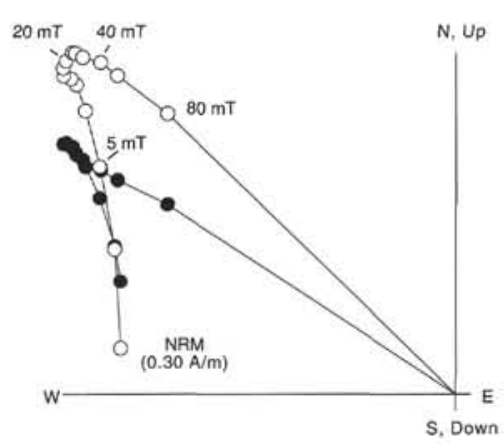

Declination

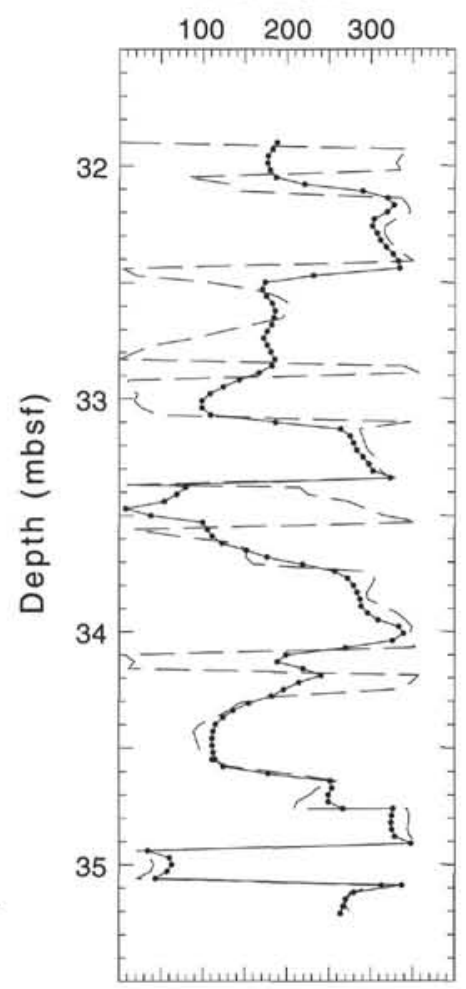

Inclination

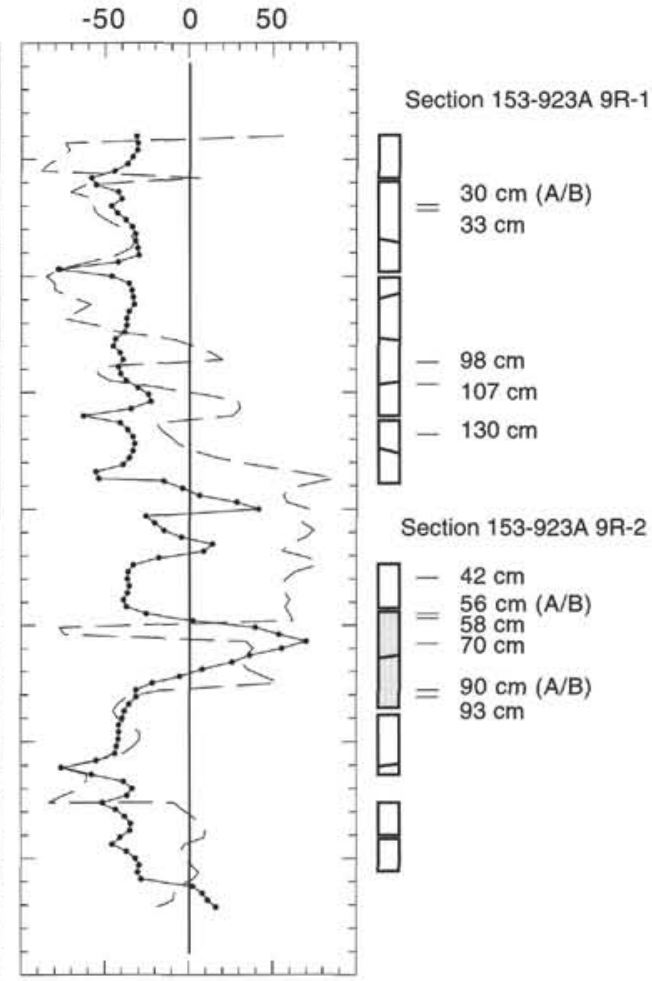


A

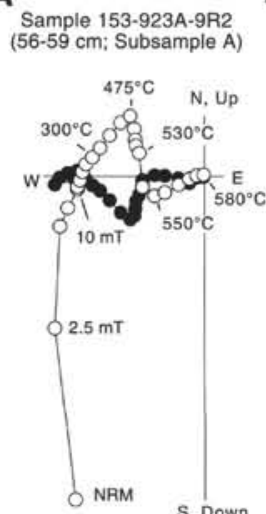

B Sample 153-923A-9R2
(56-59 cm; Subsample B)

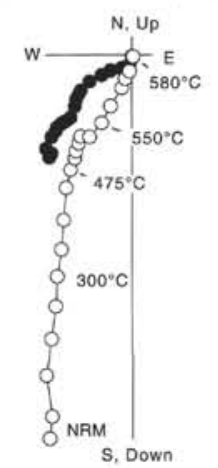

C

Sample 153-923A-9R2 $(58-61 \mathrm{~cm})$

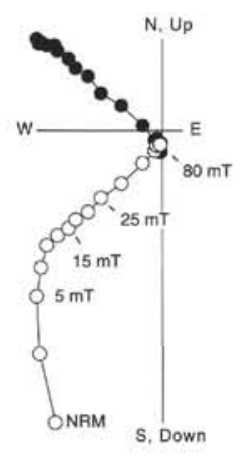

D

Sample 153-923A-9R $(70-73 \mathrm{~cm})$

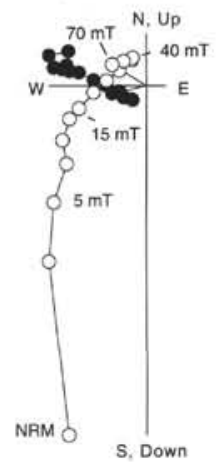

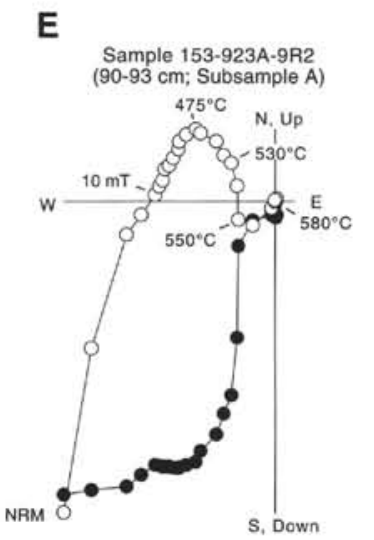

$\mathbf{F}$
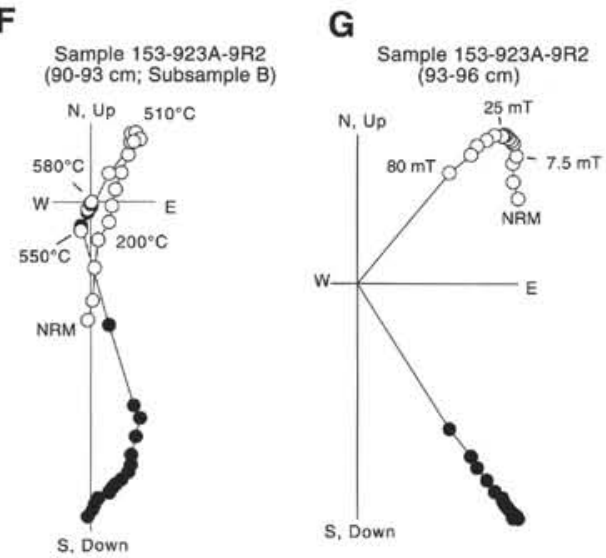

Figure 7. A-G. Vector endpoint diagrams for subsamples from Sample 153-923A-9R-2 (Piece 8). All subsamples are from a single piece and therefore have consistent azimuthal orientation. Open (solid) circles are projections onto the vertical (horizontal) plane.

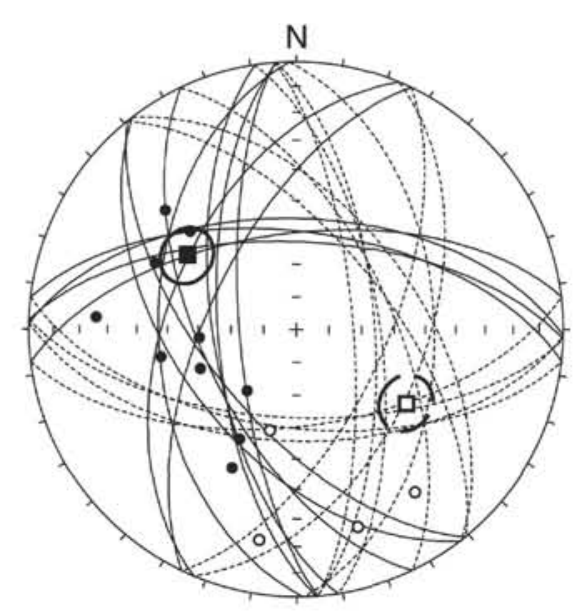

Figure 8. Equal-area projection of best-fit planes and principal components from samples from Section 153-923A-9R-2. Solid (dashed) lines indicate lower (upper) hemisphere trace of best-fit planes for all components except the lowest stability magnetization component. Solid (open) circles indicate lower (upper) hemisphere projections of principal components. Mean direction and associated $\alpha_{95}$ calculated from the intersection of the great-circle paths gives the approximate location of the end member reversed (open square) and normal (solid square) polarity directions responsible for the great-circle paths.
A

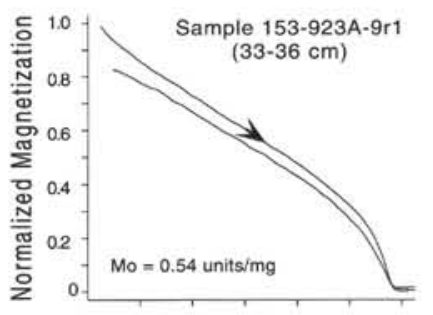

C

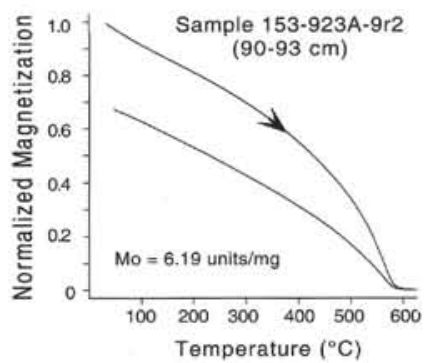

D
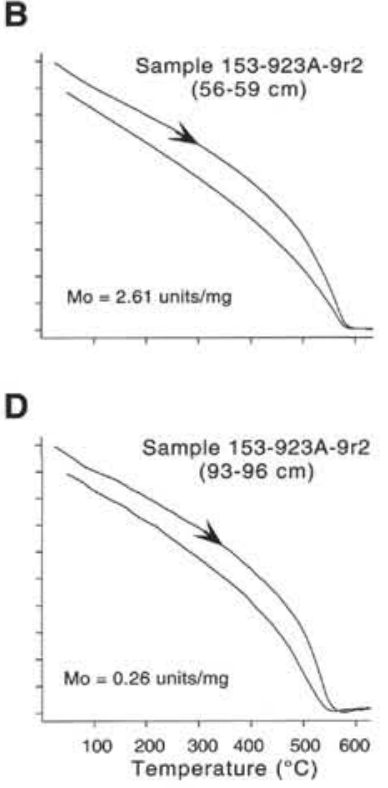

Figure 9. A-D. High-field magnetization variation with temperature for selected samples from Core 153-923A-9R. 
magnetic and alteration studies of oceanic gabbros from Hole 735B (Pariso and Johnson, 1993b; Stakes et al., 1991; Vanko and Stakes, 1991) suggest temperatures of $500^{\circ}-700^{\circ} \mathrm{C}$ for the alteration resulting in magnetite production from the alteration of olivine and pyroxene. We suggest the following possible explanation for the generation of spurious magnetization directions in gabbros from the MARK area. Alteration of pyroxene, olivine, and/or plagioclase exsolution provide three potential sources for producing similar populations of fine-grained, noninteracting magnetite grains that would be difficult to distinguish with either $\mathrm{AF}$ or thermal methods. High-temperature alteration extending over one or more polarity intervals, as is likely for gabbros formed approximately $1 \mathrm{~m} . \mathrm{y}$. ago, could therefore result in superposed normal and reversed polarity populations of otherwise identical magnetite particles. Alternative explanations are certainly possible and will be explored in future studies.

Results from gabbros sampled in the MARK area highlight the potential complexity of remanence acquisition in the intrusive portion of the crust, and hence the difficulty in evaluating the contribution of these rocks to marine magnetic anomalies. The mean remanent intensity $(1.54 \pm 2.6 \mathrm{~A} / \mathrm{m})$ and Koenigsberger ratio $(8.05 \pm 15.2)$ of gabbros from the MARK area indicate that oceanic gabbros are potentially a significant source for marine magnetic anomalies. However, the presence of dual polarities within all four sites drilled during Leg 153 suggests that the overall contribution from the lower crustal gabbros may be somewhat reduced by the competing effects of nearby normal and reversed polarity rocks. Furthermore, many samples have a complex remanence (including up to five magnetization components and apparent polarity reversals at a centimeter scale) that is apparently related to alteration during periods of opposite polarity. Although the prevalence of such complexities in the crust is difficult to evaluate, the contribution of oceanic gabbros to marine magnetic anomalies is likely to be sensitive to the timing and distribution of alteration within the intrusive layer.

\section{ACKNOWLEDGMENTS}

We thank W. Sager and an anonymous reviewer for helpful comments on the text. Funds for the Scripps Paleomagnetic laboratory have been kindly provided by the Keck Foundation. This work was supported in part by USSAC grants to the three authors.

\section{REFERENCES}

Banerjee, S.K., 1980. Magnetism of the oceanic crust: evidence from ophiolite complexes. J. Geophys. Res., 85:3556-3566.

Blakely, R.J., 1976. An age dependent, two layer model for marine magnetic anomalies. In Sutton, G.H., Manghanni, M.H., and Moberly, R. (Eds.), The Geophysics of the Pacific Ocean Basin and Its Margin. Geophys. Monogr., Am. Geophys. Union, 19:227-234.

Cande, S.C., and Kent, D.V., 1976. Constraints imposed by the shape of marine magnetic anomalies on the magnetic source. J. Geophys. Res., $81: 4157-4162$.

Cannat, M., Karson, J.A., Miller, D.J., et al., 1995. Proc. ODP, Init. Repts., 153: College Station, TX (Ocean Drilling Program).

Davis, K.E., 1981. Magnetite rods in plagioclase as the primary carrier of stable NRM in ocean floor gabbros. Earth Planet. Sci. Lett., 55:190-198.

Dinares-Turell, J., and McClelland, E., 1991. A cautionary tale for palaeomagnetists: a spurious apparent single component remanence due to overlap of blocking-temperature spectra of two components. Geophys. Res. Lett., 18:1297-1300.

Evans, M.E., McElhinny, M.W., and Gifford, A.C., 1968. Single domain magnetite and high coercivities in a gabbroic intrusion. Earth Planet. Sci. Lett., 4:142-146.

Fox, P.J., and Opdyke, N.D., 1973. Geology of the oceanic crust: magnetic properties of oceanic rocks. J. Geophys. Res., 78:5139-5154.

Gee, J., Staudigel, H., Tauxe, L., Pick, T., and Gallet, Y., 1993. Magnetization of the La Palma Seamount Series: implications for seamount paleopoles. J. Geophys. Res., 98:11743-11767.
Heirtzler, J.R., Dickson, G.O., Herron, E.M., Pitman, W.C., and Le Pichon, X., 1968. Marine magnetic anomalies, geomagnetic field reversals, and motions of the ocean floor and continents. J. Geophys. Res., 73:21192136.

Irving, E., 1970. The Mid-Atlantic Ridge at $45^{\circ} \mathrm{N}$. XIV. Oxidation and magnetic properties of basalt; review and discussion. Can. J. Earth Sci., 7:1528-1538.

Johnson, H.P., and Pariso, J.E., 1993. Variations in oceanic crustal magnetization: systematic changes in the last 160 million years. J. Geophys. Res., 98:435-445.

Kent, D.V., Honnorez, B.M., Opdyke, N.D., and Fox, P.J., 1978. Magnetic properties of dredged oceanic gabbros and source of marine magnetic anomalies. Geophys. J. R. Astron. Soc., 55:513-537.

Kikawa, E., and Ozawa, K., 1992. Contribution of oceanic gabbros to seafloor spreading magnetic anomalies. Science, 258:796-799.

Kirschvink, J.L., 1980. The least-squares line and plane and the analysis of palaeomagnetic data. Geophys. J. R. Astron. Soc., 62:699-718.

Kono, M., 1980. Magnetic properties of DSDP Leg 55 basalts. In Jackson, E.D., Koizumi, I., et al., Init. Repts. DSDP, 55: Washington (U.S. Govt. Printing Office), 723-736.

Lowrie, W., 1977. Intensity and direction of magnetisation in oceanic basalts. J. Geol. Soc. London, 133:61-82.

Mason, R.G., and Raff, A.D., 1961. Magnetic survey off the west coast of North America, $32^{\circ} \mathrm{N}$ latitude to $42^{\circ} \mathrm{N}$ latitude. Geol. Soc. Am. Bull., 72:1259-1265.

McClelland-Brown, E., 1982. Discrimination of TRM and CRM by blocking-temperature spectrum analysis. Phys. Earth Planet. Inter., 30: 405414.

McFadden, P.L., and McElhinny, M.W., 1988. The combined analysis of remagnetization circles and direct observations in palaeomagnetism. Earth Planet. Sci. Lett., 87:161-172.

Pariso, J.E., and Johnson, H.P., 1993a. Do layer 3 rocks make a significant contribution to marine magnetic anomalies? In situ magnetization of gabbros at Ocean Drilling Program Hole 735B. J. Geophys. Res., 98:1603316052 .

, 1993b. Do lower crustal rocks record reversals of the Earth's magnetic field? Magnetic petrology of gabbros from Ocean Drilling Program Hole 735B. J. Geophys. Res., 98:16013-16032.

Schulz, N.J., Detrick, R.S., and Miller, S.P., 1988. Two- and three-dimensional inversions of magnetic anomalies in the MARK area (Mid-Atlantic Ridge, $23^{\circ}$ N). Mar. Geophys. Res., 10:41-57.

Shcherbakov, V.P., McClelland, E., and Shcherbakova, V.V., 1993. A model of multidomain thermoremanent magnetization incorporating temperature-variable domain structure. J. Geophys. Res., 98:6201-6216.

Shipboard Scientific Party, 1989. Site 735. In Robinson, P.T., Von Herzen, R., et al., Proc. ODP, Init. Repts., 118: College Station, TX (Ocean Drilling Program), 89-222.

1993. Site 894. In Gillis, K., Mével, C., Allan, J., et al., Proc. ODP, Init. Repts., 147: College Station, TX (Ocean Drilling Program), 45-108.

, 1995. Introduction. In Cannat, M., Karson, J.A., Miller, D.J., et al., Proc. ODP, Init. Repts., 153: College Station, TX (Ocean Drilling Program), 5-13.

Smith, G. M., 1990. The magnetic structure of the marine basement, Rev Aquat. Sci., 2:205-227.

Stakes, D., Mével, C., Cannat, M., and Chaput, T., 1991. Metamorphic stratigraphy of Hole 735B. In Von Herzen, R.P., Robinson, P.T., et al., Proc. ODP, Sci. Results, 118: College Station, TX (Ocean Drilling Program), 153-180.

Swift, B.A., and Johnson, H.P., 1984. Magnetic properties of the Bay of Islands ophiolite suite and implications for the magnetization of oceanic crust. J. Geophys. Res., 89:3291-3308.

Talwani, M., Windisch, C., and Langseth, M., 1971. Reykjanes ridge crest: a detailed geophysical study. J. Geophys. Res., 76:473-517.

Vanko, D.A., and Stakes, D.S., 1991. Fluids in oceanic layer 3: evidence from veined rocks, Hole 735B, Southwest Indian Ridge. In Von Herzen, R.P., Robinson, P.T., et al., Proc. ODP, Sci. Results, 118: College Station, TX (Ocean Drilling Program), 181-215.

Vine, F.J., and Matthews, D.H., 1963. Magnetic anomalies over oceanic ridges. Nature, 199:947-949.

Date of initial receipt: 2 August 1995

Date of acceptance: 22 March 1996

Ms 153SR-042 